\title{
Redningen av de danske jødene i oktober 1943
}

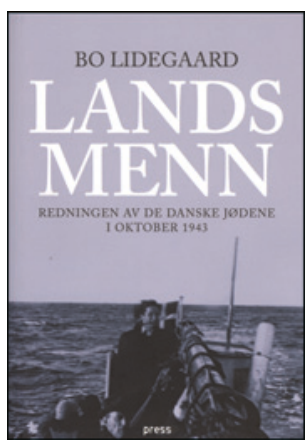

Vel et år etter at de norske jødene ble offer for den tyske industrielle «rensingen» av de okkuperte europeiske landområdene, var det Danmarks tur.

Forholdene i de to landene var etter okkupasjonen 9. april 1940 vidt forskjellige. Danmark hadde kapitulert og derved oppnådd en pragmatisk samarbeidslinje, med regjering og statsadministrasjon intakt, og med kongehuset som et symbol på den passive motstanden som eksisterte i dette «mønsterprotektoratet». Dette klarte styresmaktene å opprettholde helt frem til unntakstilstanden i august 1943, og da regjeringen gikk av, benyttet de nazistiske makthaverne tidspunktet til å iverksette «den endelige løsningen» også i Danmark.

At forløpene ble totalt forskjellige for jødene i de to landene har nok delvis en høyst relevant historisk bakgrunn. Mens Danmark hadde gitt jødene statsborgerlige rettigheter i 1814, hadde Norge som kjent i den nye Grunnlovens $\S 2$ «forbudt jøder adgang til riket». I Danmark «hadde man intet jødeproblem»: Man hadde ikke registrert minoriteten, som hadde en flere hundre års historie i landet. Det var ikke mer enn ca. 8000 jøder i landet, og selv om et stort antall hadde innvandret fra Russland og Baltikum i begynnelsen av århundret, og et antall hadde kommet som flyktninger i årene før krigen, hadde Danmark et innslag av velintegrerte og til dels innflytelsesrike jødiske borgere innen mange samfunnsgrener.

\section{Dramatisk maktkamp}

Lidegaards bok er et drivende historisk drama, der vi parallelt med nøkterne beskrivelser av regjeringens og statsadministrasjonens balansegang opp mot okkupantens representanter, får beskrevet den tilsvarende maktkampen mellom okkupantens ulike maktpersoner og baser, i Danmark og i Berlin. I tillegg beskrives internasjonale reaksjoner og aktiviteter, særlig de svenske tiltakene, og alt dette som bakteppe for fire dagbøker forfattet av representanter for ulike jødiske familier. Mens vi får innblikk i politiske avgjørelser, fremstøt, tilbaketrekninger og kompromisser, ser vi hvordan dette påvirker enkeltpersonene i deres overlegninger og endelige beslutninger.

Vi ser dilemmaene som administrasjonsleder Svenningsen har i sine bestrebelser og forhandlinger for å lindre de verste tragediene som truer landsmennene, som aldri har opplevd «å være annerledes».

Vi er med i maktkampen i den tyske leiren, der stattholder Best prøver å innfri Eichmanns ønsker, samtidig som han vil dele den eventuelle kommende skylden med Wehrmachts' sjef og sine underordnede. Og vi forstår angsten familiene har ved å skulle forberede seg og senere bryte opp fra sine vante tilværelser og gjennomgå alle mulige prøvelser for å komme over til det nøytrale Sverige.

\section{Flukten}

Det er imponerende å lese om flukten over Øresund: at man fra et organisasjonsmessig elendig utgangspunkt, ved et kollektivt krafttak for å redde «landsmenn», klarte å frakte mer enn 7000 flyktninger $\mathrm{i}$ trygghet på den andre siden av sundet i løpet av noen dager.

For de som har vært på ferietur i de små nordsjællandske landsbyene, er det vanskelig å forestille seg hundrevis av flyktninger løpende med vesker og kofferter fra hus til hus i Gilleleje, på jakt etter båtplass. At det lyktes ved aktiv hjelp fra dansk politi og kystvakt, og sannsynligvis også stilltiende aksept og noe passivitet fra den tyske vernemakten, gjør ikke det politiske og folkelige forarbeidet mindre.

Boken er en delikat trykksak. De mange gode illustrasjonene hjelper på forståelsen, og referanselisten er meget fullstendig for den som vil sette seg ytterligere inn i materialet. Den norske utgaven har fått et kapittel som grundig og oversiktlig gir en introduksjon til de viktigste forskjellene ved den tyske okkupasjonen av de to landene. Dermed gis det noen forklaringsbakgrunner for hvorfor den lille norsk- jødiske minoriteten fikk en annen skjebne i 1942 enn den danske. Men på tross av de politiske og tidsmessige ulikhetene er kanskje nettopp tittelen - Landsmenn - nøkkelen til at det gikk så annerledes.

\section{Rolf Kirschner}

Prakt. spesialist, BestHelse Nordstrand Oslo 